\title{
Two ploidy levels of genetically delimited groups of the Calypogeia fissa complex (Jungermanniopsida, Calypogeiaceae)
}

\section{Katarzyna Buczkowska, Bartosz Hornik \& Magdalena Czołpińska*}

Department of Genetics, Faculty of Biology, Adam Mickiewicz University, Umultowska 89, 61-614 Poznań, Poland

* corresponding author (e-mail: magczo@amu.edu.pl)

\begin{abstract}
Calypogeia fissa is a suboceanic-mediterrean and amphiatlantic species, which comprises two subspecies: C. fissa subsp. fissa occurring in Europe and C. fissa subsp. neogea Schust. known from North America. Recently, within the European part of distribution, three groups $\left(\mathrm{P}_{\mathrm{S}}, \mathrm{P}_{\mathrm{B}}\right.$ and $\left.\mathrm{G}\right)$ were distinguished with the aid of genetic and molecular markers. The flow cytometry results revealed that two of the detected groups of the European C. fissa, which are frequent in $\mathrm{Poland}_{(\mathrm{P}}$ and $\left.\mathrm{P}_{\mathrm{B}}\right)$, differ in ploidy level: the $\mathrm{P}_{\mathrm{S}}$ group is haploid, whereas the $\mathrm{P}_{\mathrm{B}}$ group is diploid. Isozyme pattern at two loci may suggest an allopolyploid origin of the diploid $\mathrm{P}_{\mathrm{B}}$ group.
\end{abstract}

Key words: Calypogeia, bryophytes, liverworts, ploidy level, flow cytometry, isozyme markers

\section{Introduction}

Molecular and cytogenetic studies of liverworts have revealed that some species are genetically heterogeneous and, in fact, consist of morphologically cryptic or nearly cryptic taxa (Shaw 2001). Cytological mechanisms, such as polyploidization, was one of the speciation ways within such complexes e.g. Pellia borealis (Odrzykoski et al. 1996), Corsinia coriandrina (Boisselier-Dubayle \& Bischler 1998), Porella bauerii (Boisselier-Dubayle et al. 1998a), or the Reboulia hemisphaerica complex (Boisselier-Dubayle et al. 1998b) consisted of haploid and polyploid taxa. In some of the above examples, the species with a duplicated chromosome number are allopolyploids which arose as a result of hybridization and its parental species were identified e.g. two haploid cryptic species of the P. epiphylla complex (S and $\mathrm{N})$ are proved to be parental species of the polyploid P. borealis (Odrzykoski et al. 1996; Fiedorow et al. 2001). In turn, P. bauerii is a hybrid between two different species, namely $P$. platyphylla and $P$. cordeana (Boisselier-Dubayle et al. 1998a).

Hybridization and genome duplication are also important processes of speciation in the Calypogeia genus. The genus includes species with haploid $(\mathrm{n}=9)$ and dip- loid $(\mathrm{n}=18)$ set of chromosome number (Newton 1973; Fritch 1991). Moreover, polymorphism in chromosome numbers was observed in some species e.g. C. neesiana, C. suecica, $C$. azurea, in which plants with $\mathrm{n}=9$ or $\mathrm{n}=18$ were noted depending on geographic origin (Newton 1973; Fritch 1991; Paton 1999; Chudzińska et al. 2001). Evidence from cytological and isozyme studies revealed that three species with diploid set of chromosomes: C. azurea, C. muelleriana and C. sphagnicola f. paludosa have an allopolyploid origin (Buczkowska et al. 2004; Buczkowska et al. 2012a). For C. fissa, only one chromosome number $(\mathrm{n}=18)$ was reported (Lorbeer 1934; Müller 1951-1958; Damsholt 2002).

Calypogeia fissa - a suboceanic-mediterrean and amphiatlantic species (Mller 1951-1958; Schuster 1969) comprises two subspecies: C. fissa subsp. fissa occurring in Europe and C. fissa subsp. neogea Schust. reported from North America (Schuster 1969; Damsholt 2002). Recently, within the European part of distribution, three groups $\left(\mathrm{P}_{\mathrm{S}}, \mathrm{P}_{\mathrm{B}}\right.$ and $\left.\mathrm{G}\right)$ were distinguished with the aid of genetic and molecular markers (Buczkowska 2004; Buczkowska et al. 2012b). The $\mathrm{P}_{\mathrm{s}}$ group, which comprises much smaller plants than the two remaining groups, is the most distinct both in terms of genetic and morphological features (Buczkowska 2004; 
Buczkowska et al. 2011). A clear difference in the size of plants suggests differences in ploidy level between these groups. In the present study, we used flow cytometry to estimate the ploidy level of two genetically distinct groups $\left(\mathrm{P}_{\mathrm{S}}\right.$ and $\left.\mathrm{P}_{\mathrm{B}}\right)$ of the $C$. fissa complex occurring in Poland. Isozyme markers were also applied in order to check whether the studied groups may have arisen as a result of allopoliploidization.

\section{Material and methods}

\subsection{Plant material}

Plants used in the present studies were initially determined as belonging to the $C$. fiss a complex on the basis of morphological traits and oil body characters according to Schuster (1969) and Szweykowski (2006). Next, genetic groups $\left(\mathrm{P}_{\mathrm{S}}\right.$ and $\left.\mathrm{P}_{\mathrm{B}}\right)$ of $C$. fissa subsp. fissa were identified on the basis of isozyme markers according to Buczkowska (2004). In isozyme analysis, C. fissa subsp. neogea was used for comparison (Table 1). Electrophoretic separation of the following enzyme systems: EST, GOT, GDH and PGD was conducted according to the procedure described by Wendel \& Weeden (1989). Details of cell extract preparation and buffer systems used are included in Buczkowska \& Bączkiewicz (2011). Detected alleles were labeled in accordance with previous studies of Calypogeia (Buczkowska 2004; Buczkowska et al. 2004; Buczkowska \& Bączkiewicz 2011).

\subsection{Flow cytometry}

About 10-15 shoots from each accession carefully cleaned were used for analyses. A modified

Table 1. Collection sites of the studied Calypogeia samples

\begin{tabular}{|c|c|c|c|}
\hline $\begin{array}{l}\text { Sample } \\
\text { No. }\end{array}$ & Locality & Collector & $\begin{array}{c}\text { Herbarium } \\
\text { No. }\end{array}$ \\
\hline \multicolumn{4}{|c|}{ Calypogeia fissa subsp. fissa - group $\mathrm{P}_{\mathrm{s}}$} \\
\hline 1 & W Poland, Lubuskie Province, Bogumiłów near Żary & SR & $42628^{*}$ \\
\hline 2 & Central Poland, Wielkopolskie Province, Antonin near Ostrów Wlkp. & $\mathrm{KB}$ & $42225 *$ \\
\hline 3 & Central Poland, Wielkopolskie Province, Antonin near Ostrów Wlkp. & $\mathrm{KB}$ & 42227 \\
\hline 4 & Central Poland, Wielkopolskie Province, Antonin near Ostrów Wlkp. & $\mathrm{KB}$ & $42629 *$ \\
\hline \multicolumn{4}{|c|}{ Calypogeia fissa subsp. fissa - group $\mathrm{P}_{\mathrm{B}}$} \\
\hline 5 & NW Poland, Pomorskie Province, Lake Małe Sitno near Czarna Dąbrówka & $\mathrm{KB}, \mathrm{AB}$ & $42345^{*}$ \\
\hline 6 & NW Poland, Pomorskie Province, Lake Kamień near Miastko & $\mathrm{KB}, \mathrm{AB}$ & $42205^{*}$ \\
\hline 7 & W Poland, Lubuskie Province, Starosiedle forest division & SR, KB & $42275^{*}$ \\
\hline 8 & W Poland, Lubuskie Province, Rzeczyca river, humus in Carici elongate-Alnetum & SR & 42630 \\
\hline \multicolumn{4}{|c|}{ Calypogeia fissa subsp. neogea } \\
\hline 9 & North America, North Carolina, the Southern Appalachian, Dry Falls & BS & 42626 \\
\hline 10 & North America, North Carolina, the Southern Appalachian, Dry Falls & BS & 42622 \\
\hline 11 & North America, North Carolina, the Southern Appalachian & BS & 42620 \\
\hline 12 & North America, North Carolina, the Southern Appalachian & $\mathrm{BS}$ & 42617 \\
\hline \multicolumn{4}{|c|}{ Calypogeia muelleriana s. str. (typical form $\left.=\operatorname{group} \mathrm{A}^{1}\right)$} \\
\hline 13 & NE Poland, Pomorskie Province, Lake Orle near Miastko & $\mathrm{KB}, \mathrm{AB}$ & $41182 *$ \\
\hline 14 & NW Poland, Pomorskie Province, Lake Lubygość near Kartuzy & $\mathrm{KB}, \mathrm{AB}$ & 42214* \\
\hline 15 & W Poland, Lubuskie Province, Starosiedle forest division & $\mathrm{KB}, \mathrm{AB}$ & $42323 *$ \\
\hline \multicolumn{4}{|c|}{ Calypogeia muelleriana $\left(\right.$ atypical form $=$ group $\mathrm{B}^{1}$ ) } \\
\hline 16 & NE Poland, Warmińsko-Mazurskie Province, Lake Godle near Ełk & $\mathrm{KB}, \mathrm{AB}$ & $41706^{*}$ \\
\hline 17 & NE Poland, Warmińsko-Mazurskie Province, Lake Godle near Ełk & $\mathrm{KB}, \mathrm{AB}$ & $41707^{*}$ \\
\hline 18 & NW Poland, Pomorskie Province, Lake Lubygość near Kartuzy & $\mathrm{KB}, \mathrm{AB}$ & $42220 *$ \\
\hline \multicolumn{4}{|c|}{ Calypogeia azurea } \\
\hline 19 & S Poland, Tatra Mts., NE slope of Skupinów Upłaz Mt. & $\mathrm{KB}, \mathrm{AB}$ & $41776^{*}$ \\
\hline 20 & S Poland, Gorce Mts., Ochotnica Dolna Kudowy & $\mathrm{KB}$ & 42390* \\
\hline 21 & SE Poland, Bieszczady Mts., Wetlina, Górna Solinka Valley & KB & $41948^{*}$ \\
\hline \multicolumn{4}{|c|}{ Calypogeia suecica } \\
\hline 22 & S Poland, Tatra Mts., stream near Lake Toporowy Staw Wyżni & $\mathrm{KB}, \mathrm{AB}$ & $41727^{*}$ \\
\hline 23 & S Poland, Beskid Sądecki Mts., stream Czarny & $\mathrm{KB}$ & 42366* \\
\hline 24 & SE Poland, Bieszczady Mts., Górna Solinka Valley & KB & $41936^{*}$ \\
\hline
\end{tabular}

Explanations: ${ }^{1}$ - according to Buczkowska \& Bączkiewicz (2011); collectors, AB - Alina Bączkiewicz, BS - Blanka Shaw, KB - Katarzyna Buczkowska, SR - Stanisław Rosadziński; * - samples used for flow cytometry 
procedure described by Šmarda (2006) was used to prepare the samples. Plant material was ground in a mortar with Otto I buffer $(0.1 \mathrm{M}$ citric acid, $0.5 \%$ Tween 20). The crude nuclei suspension was filtered through a $30 \mu \mathrm{m}$ nylon filter. $1 \mathrm{~mL}$ of Otto II buffer $\left(0.4 \mathrm{M} \mathrm{Na}_{2} \mathrm{HPO} 4.12 \mathrm{H}_{2} \mathrm{O}\right)$ supplemented with $2 \mu \mathrm{g} / \mathrm{mL}$ 4,6-diamidino-2-phenylindole (DAPI) was then added to the nuclei suspension. C. suecica (Arnell \& J. Press.) Müll. Frib., the haploid ( $\mathrm{n}=9$ ) species (Buczkowska et al. 2004) was used as external standard. For verification of the results, ploidy level was also tested by flow cytometry for samples of other species with known $(\mathrm{n}=18)$ chromosome numbers: C. azurea Stotler \& Crotz, $C$. muelleriana (Chudzińska et al. 2001; Buczkowska et al. 2004). C. muelleriana is genetically heterogenous and consists of two taxa: C. muelleriana s.str. (typical form, group A) and the new taxon - group B (Buczkowska \& Bączkiewicz 2011). Chromosome number $(n=18)$ was determined only for the A group. Therefore, in the present studies the DNA content was measured for both C. muelleriana groups. Three different samples of each $C$. fissa group and remaining species were measured (Table 1). The measurements were repeated 3 times for each sample.

\section{Results}

The DNA content of groups $\mathrm{P}_{\mathrm{S}}$ and $\mathrm{P}_{\mathrm{B}}$ of the $C$. fissa complex was determined by flow cytometric measurements and compared with reference species (Fig. 1). Nuclei DNA content in specimens determined by genetic markers as the $\mathrm{P}_{\mathrm{S}}$ group of $C$. fissa subsp. fissa
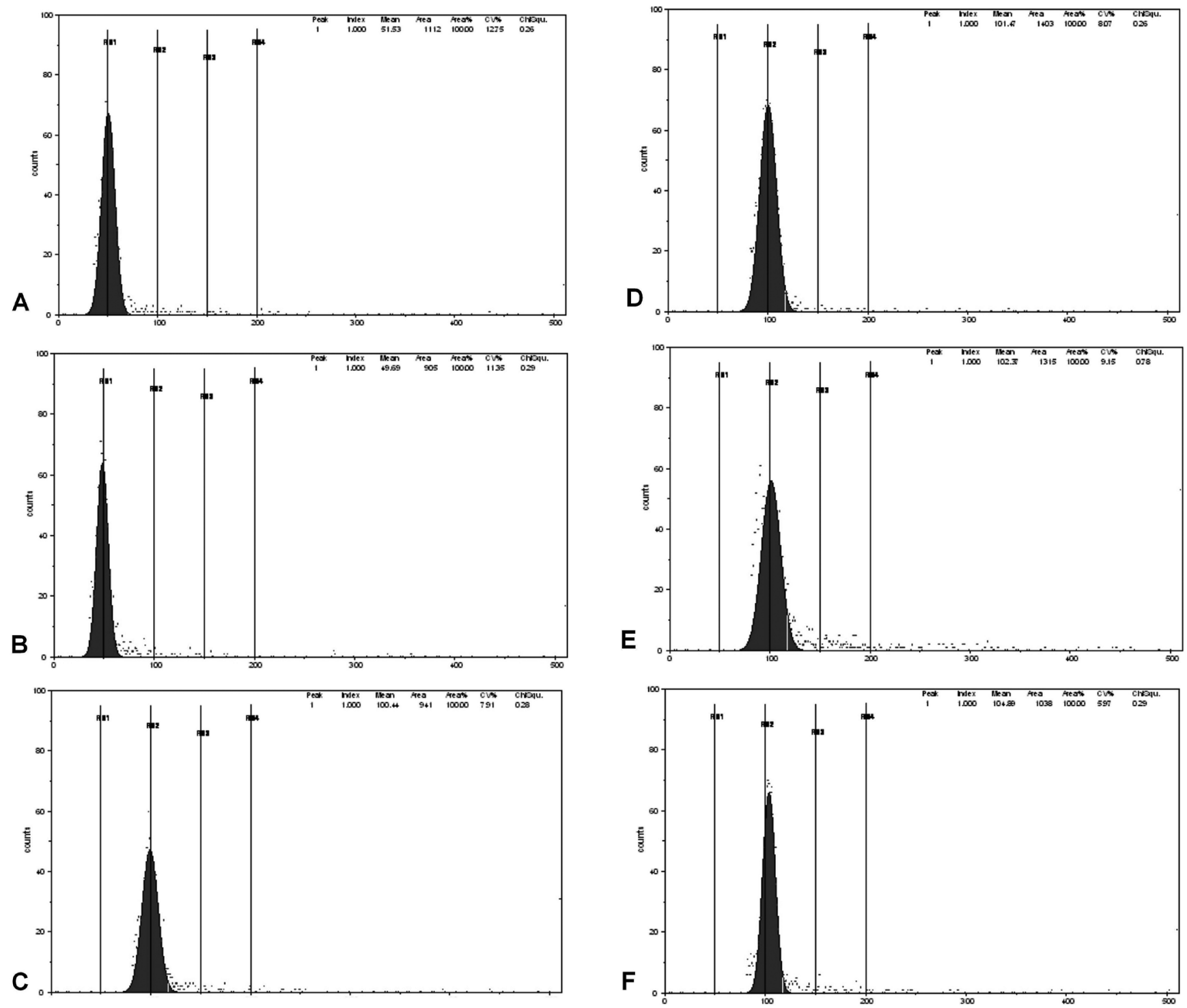

Fig. 1. Histograms of flow cytometry analysis of DNA content in the studied groups of the Calypogeia fissa complex and references species Explanations: A - Calypogeia suecica ( $\mathrm{n}=9), \mathrm{B}-$ Calypogeia fissa subsp. fissa group $\mathrm{P}_{\mathrm{s}}, \mathrm{C}-$ Calypogeia fissa subsp. fissa group $\mathrm{P}_{\mathrm{B}}, \mathrm{D}-\mathrm{Calypogeia}_{\text {azurea }}$ $(\mathrm{n}=18), \mathrm{E}-$ Calypogeia muelleriana $\mathrm{s} . \mathrm{str}-\operatorname{group} \mathrm{A}(\mathrm{n}=18), \mathrm{F}-$ Calypogeia muelleriana - group $\mathrm{B} ; \mathrm{RN}($ range-gate $), \mathrm{RN} 1=(2 \mathrm{C}), \mathrm{RN} 2=(4 \mathrm{C}), \mathrm{RN} 3=(8 \mathrm{C})$ 

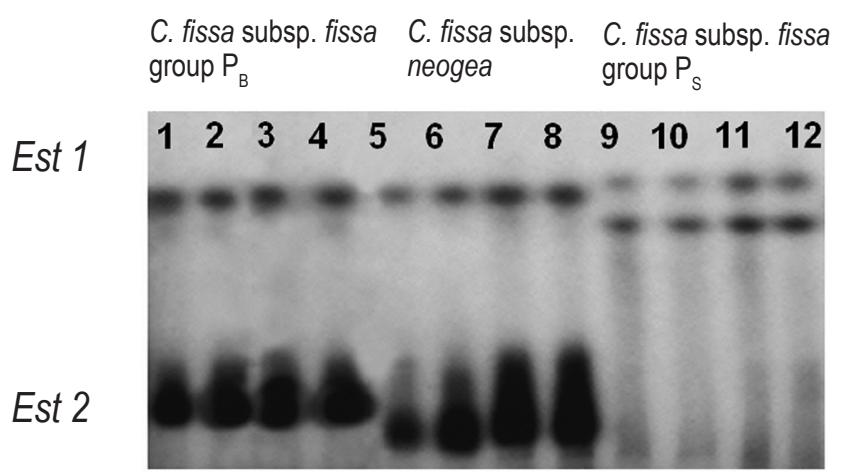

Got

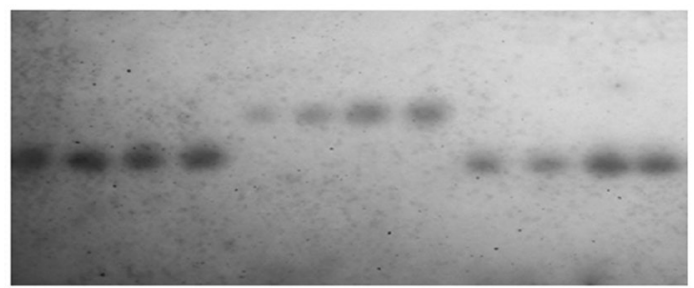

Gdh

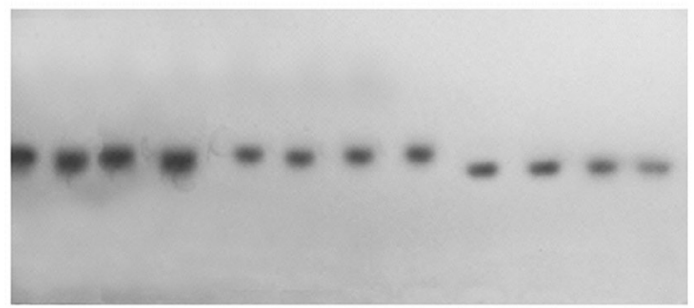

Pgd

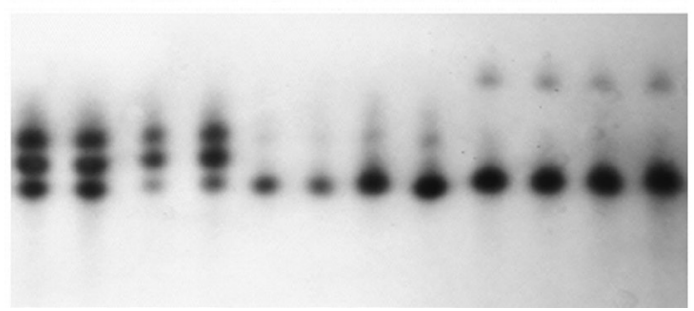

Fig. 2. Isozyme phenotypes of studied groups of the Calypogeia fissa complex

Explanations: 1-4 Calypogeia fissa subsp. fissa group $\mathrm{P}_{\mathrm{B}}$, 5-8 C. fissa subsp. neogea, 9-12 C. fissa subsp. fissa group $\mathrm{P}_{\mathrm{S}}$

was equal to the DNA content found in C. suecica, with known $(\mathrm{n}=9)$ chromosome number and half as high as in specimens from the $\mathrm{P}_{\mathrm{B}}$ group of $C$. fissa subsp. fissa. DNA content of the $\mathrm{P}_{\mathrm{B}}$ group was comparable to the values obtained for C. azurea and C. muelleriana s.str. $(\mathrm{n}=18)$. DNA ploidy level of C. muelleriana - group B assessed by flow cytometry was the same as $C$. muelleriana s.str. with $(\mathrm{n}=18)$ chromosome number (Fig. $1)$.

Isozyme phenotypes obtained for the studied groups of the $C$. fissa complex are given in Fig. 2. For the $\mathrm{P}_{\mathrm{S}}$ and $\mathrm{P}_{\mathrm{B}}$ groups, two different phenotypes in the EST enzyme system and only one, the same for both groups in Got locus, were found. Two different phenotypes were observed in the $P g d$ locus: single-banded in all samples of the $\mathrm{P}_{\mathrm{S}}$ group and triple-banded pattern in samples of the $\mathrm{P}_{\mathrm{B}}$ group. The triple-banded isozyme phenotype possibly represented heterozygous genotypes. Hetero- zygous genotype in the $\mathrm{P}_{\mathrm{B}}$ group was also observed in $G d h$, which, in heterozygote, appeared always as a slightly diffused broad band because of its multiple banded phenotype.

\section{Discussion}

In previous experiments, three distinct groups $\left(\mathrm{P}_{\mathrm{S}}, \mathrm{P}_{\mathrm{B}}\right.$ and $\mathrm{G}$ ) within European subspecies of $C$. fissa were detected by isozyme and molecular studies (Buczkowska 2004; Buczkowska et al. 2012b). Results of the present study support the hypothesis that $C$. fissa is a complex species consisting of genetically isolated taxa. Two of the examined groups of European $C$. fissa, which are frequent in Poland $\left(\mathrm{P}_{\mathrm{S}}\right.$ and $\left.\mathrm{P}_{\mathrm{B}}\right)$, differ in their ploidy level. The $\mathrm{P}_{\mathrm{S}}$ group has half as high DNA content as in specimens from the $\mathrm{P}_{B}$ group. Nuclei DNA content in the $\mathrm{P}_{\mathrm{S}}$ group is equal to the DNA amount found in C. suecica, with a known $(\mathrm{n}=9)$ chromosome number, whereas in the $\mathrm{P}_{\mathrm{B}}$ group is comparable with $C$. azurea and C. muelleriana - species with $\mathrm{n}=18$ (Buczkowska et al. 2004). In view of the obtained results, the studied groups of the $C$. fissa complex can be regarded as a separate species in accordance with the biological species concept, which assume reproductive isolation. The $\mathrm{P}_{\mathrm{S}}$ and $\mathrm{P}_{\mathrm{B}}$ groups of $C$. fissa subsp. fissa are haploid and diploid species, respectively. Unfortunately, due to the lack of a sufficient amount of living material we failed to identify the ploidy level in the G group of European C. fissa and C. fissa subsp. neogea. Data concerning the ploidy level in bryophytes are still incomplete as chromosome counting in some species is very difficult. Flow cytometry is a very helpful method in determining the ploidy level in bryophyte species (Śliwińska et al. 2000; Ricca et al. 2008; Temsch et al. 2010).

Isozyme phenotypes at two loci ( $P g d$ and $G d h$ ) observed in the $\mathrm{P}_{\mathrm{B}}$ group express fixed heterozygous pattern which can suggest their allopolyploid origin. Similarly, fixed heterozygotes in the same loci were also found in diploid $(\mathrm{n}=18)$ C. sphagnicola f. paludosa regarded as allopolyploids (Buczkowska et al. 2012a). Previous studies and known chromosome number indicate that polyploidization played an important role as the speciation process in the Calypogeia genus (Newton 1973; Inoue 1976; Fritch 1991; Buczkowska et al. 2004). Two cytotypes were detected in the $C$. sphagnicola complex: haploid C. sphagnicola f. sphagnicola and diploid C. sphagnicola f. paludosa which were recognized as species of allopolyploid origin based on fixed heterozygosity in isozyme loci (Buczkowska et al. 2004; Buczkowska et al. 2012a). The isozyme loci also provided evidence for an allopolyploid origin of C. azurea and both taxa (group A and B) of the C. muelleriana complex (Buczkowska et al. 2004; Buczkowska \& Bączkiewicz 2011). Results of isozyme 
and molecular studies give evidence that in bryophytes, allopolyploids are more common than it was previously assumed (Såstad 2005). An allopolyploid origin was detected in several liverwort species, e.g. P. borealis (Fiedorow et al. 2001), P. bauerii (Boisselier-Dubayle et al. 1998) and mosses e.g. Rhizomnium pseudopunctatum (Jankowiak et al. 2005), Plagiomnium curvatulum (Jankowiak-Siuda et al. 2008).
Acknowledgements. This work was financially supported by the grant no. N303 344235 from the Polish Ministry of Science and Higher Education. We wish to thank Krystyna Strycharczuk MSc for help in assessment of DNA content and Patrycja Gonera for help in the laboratory. We would like to thank Blanka Shaw and Stanisław Rosadziński for providing plant material.

\section{References}

Boisselier-Dubayle M. C. \& Bischler H. 1998. Allopolyploidy in the thalloid liverwort Corsinia (Marchantiales). Bot. Acta 111: 490-496.

Boisselier-Dubayle M. C., Lambourdiere J. \& Bischler H. 1998a. The leafy liverwort Porella baueri (Porellaceae) is an allopolyploid. Pl. Syst. Evol. 210: 175-197.

Boisselier-Dubayle M. C., Lambourdiere J. \& Bischler H. 1998b. Taxa delimitation in Reboulia investigated with morphological, cytological, and isozyme markers. Bryologist 101: 61-69.

Buczkowska K. 2004. Genetic differentiation of Calypogeia fissa (L.) Raddi (Hepaticae, Jungermanniales) in Poland. P1. Syst. Evol. 247: 187-201.

Buczkowska K., Odrzykoski I. J. \& Chudzińska E. 2004. Delimitation of some European species of Calypogeia Raddi (Hepaticae Jungermnniales) based on cytological characters of oil bodies and multienzyme phenotype. Nova Hedwigia 78: 147-163.

Buczkowska K. \& BAczkiewicz A. 2011. New taxon of the genus Calypogeia (Jungermanniales, Hepaticae) in Poland. Acta Soc. Bot. Pol. 80: 327-333.

Buczkowska K., Sawicki J., Szczecińska M., Klama H. \& BĄCZKIEwICZ A. 2012a. Allopoliploid speciation of Calypogeia sphagnicola (Jungermanniopsiada, Calypogeiaceae) based on isozyme and DNA markers. Pl. Syst. Evol. 298: 549-560.

Buczkowska K., Gonera P. \& Hornik B. 2012b. PCR-based molecular markers for identyfication of taxa from the Calypogeia fissa complex (Jungermanniopsida, Calypogeiaceae). Biodiv. Res. Conserv. 28: 9-18.

Buczkowska K., SAwicki J., SzczecińsKa M., Rosadziński S., RABSKA M. \& BĄCZKIEWICZ A. 2011. Two morphologically distinct groups of the Calypogeia fissa complex were found in Europe. Biodiv. Res. Conserv. 23: 7-19.

Chudzińska E., Barczak H. \& Szweykowski J. 2001. Chromosome numbers in some Polish critical or rare Liverworts (Hepaticae). Cryptogamie, Bryol. 22(2): 85-93.

DAMsholt K. 2002. Illustrated Flora of Nordic Liverworts and Hornworts. 840 pp. Nordic Bryological Society, Lund.

Fiedorow P., Odrzykoski I. J., Szweykowski J. \& SzweYkowska-KulińsKa Z. 2001. Phylogeny of the European species of the genus Pellia (Hepaticae, Metzgeriales) based on the molecular data from nuclear $t R N A^{\text {Leu }}$ (CAA) intergenic sequences. Gene 262: 309-315.
Fritch R. 1991. Index to bryophyte chromosome counts. Bryoph. Bibl. 40: 19-20.

INOUE H. 1976. Chromosome studies in some Arctic hepatics. Bull. Nat. Sci. Mus. Tokyo Ser. B 2: 39-46.

Jankowiak-Siuda K., Pacak A., Odrzykoski I., Wyatt R. \& Szweykowska-Kulińska Z. 2008. Organellar inheritance in the allopolyploid moss Plagiomnium curvatulum. Taxon 57: 137-143.

JANKOWIAK K., RYBARCZYK A., WyATT R., ODRZYKOSKi I., PACAK A. \& SZWEyKOWSKA-KulinsKa Z. 2005. Organellar inheritance in the allopolyploid moss Rhizomnium pseudopunctatum, Taxon 54: 383-388.

LORBEER G. 1934. Zytologie der Lebermoose mit besonderer Berücksichtigung allgemeiner Chromosomenfragen. I. Teil. Jahrb. Wiss. Bot. 80: 567-818.

MüLleR K. 1951-1958. Die Lebermoose Europas In: Dr L. Rabenhorst's Kryptogamen Flora von Deutschland Österreich und der Schweiz. 3rd ed. Akademische Verlagsgesellaschaft Geest \& Portig K.-G., Leipzig.

Newton M. 1973. Chromosome studies in some British and Irish bryophytes, II. J. Bryol 7:379-398.

Odrzykoski I. J., ChudzińsKa E. \& Szweykowski J. 1996. The hybrid origin of the polyploid liverwort Pellia borealis. Genetica 98: 75-86

Paton J. 1999. The Livervort Flora of the British Isles. Harley Books, Colchester.

Ricca M., Beecher F. W., Boles S. B., Temsch E., Greilhuber J., Karlin E. F. \& Shaw A. J. 2008. Cytotype variation and allopolyploidy in North American species of the Sphagnum subsecundum complex (Sphagneceae). Am. J. Bot. 95: 1606-1620.

SÅsTAD S. M. 2005. Patterns and mechanisms of polyploid formation in bryophytes. Regnum Vegetabile 143: 317-334.

Schuster R. M. 1969. The Hepaticae and Anthocerotae of North America east of the hundredth meridian vol 2, Columbia University Press, New York-London.

SHAw A. J. 2001. Biogeographic patterns and cryptic speciation in bryophytes. J. Biogeog. 28: 253-261.

ŠMARDA P. 2006. DNA ploidy levels and intraspecific DNA content variability in Romanian fescues (Festuca, Poaceae) measured in fresh and herbarium material. Folia Geobot. 41: 417-432.

Szweykowski J. 2006. An annotated checklist of Polish liverworts. In: Z. MireK (ed.) Biodiversity of Poland, 4, 
114 pp. W. Szafer Institute of Botany, Polish Academy of Sciences, Kraków.

ŚLiwińsKa E., KrZakowa M. \& Melosik I. 2000. Estimation of ploidy level in four Sphagnum species (Subsecunda section) by flow cytometry. In: M. KRZAKOwA \& I. MelosiK (eds.). The variability in Polish populations of sphagnum taxa (Subsecunda section) according to morphological anatomical and biochemical traits. Bogucki Press SC, Poznań, pp. 137-150.
Temsch E., Greilhuber J. \& Krisai R. 2010. Genome size in liverworts. Preslia 82: 63-80.

Wendel J. E. \& WeEden N. F. 1989. Visualisation and interpretation of plant isozymes. In: D. E. Soltis \& P. S. Soltis (eds.). Isozymes in Plant Biology, pp. 4-45. Dioscorides Press, Portland, Oregon. 